\title{
Physical seed dormancy in Abrus precatorious (Ratti): a scientific validation of indigenous technique
}

\author{
Rajender Kumar Sharma \\ Department of Botany, Deshbandhu College, University of Delhi, Delhi 110019, India \\ Corresponding author. E-mail: rksharmabio@yahoo.co.in
}

(Received 01 November 2020; Revised 20 November 2020; Accepted 22 November 2020)

\begin{abstract}
Seeds of Abrus precatorius L. (Fabaceae) were used as weight measure by Indigenous people. Where, the seeds were referred as Ratti; a traditional Indian unit of mass measurement. Seed weight fluctuates depending upon age, moisture, storage-period/conditions. Therefore, use of seeds as a weighing unit become dubious and need to be validated. For this purpose, seeds of $A$. precatorious were subjected to different moisture conditions and periodically monitored. Surprisingly, there was no change in seed weight was observed, indicating the impermeability of seed coat. The later was confirmed by scarification of seed coat which resulted in 53\% increase in seed weight against $0 \%$ in control. Further, presence of a potent toxin (abrin) in the seed coat protects it from pests and microbes, and contributes to the maintenance of impermeability for longer period of time. The data validates the use of $A$. precatorious seeds as a weighing unit (ratti) by the indigenous people and discussed.
\end{abstract}

Keywords: Abrus precatorious; ITK-validation; Physical dormancy

\section{Introduction}

Indigenous techniques (ITKs) are treasure troves of ancient wisdom and developed through trial-anderror, experiences gained over the centuries, and are time tested (Mohapatra, 2018) but, generally not substantiated by any scientific evidences. Seeds of Abrus precatorius L. (Fabaceae) an indigenous medicinal plant commonly known as Rosary pea, Ratti or Gunja are very attractive, uniform in size and shape (Fig. 1) and are used as weight measure by indigenous people including Indian gold smiths. Where, the seeds were referred as Ratti, a traditional Indian unit of mass measurement (Shrivastava, 2017). Generally, seed weight changes or fluctuate with change in environmental conditions (temperature, relative humidity), storage-period and storage-conditions (McGilp et al., 2020). Further, seeds weight generally decline with the progression of storage/ageing due to metabolic breakdown of stored food, microbial degradation, pest infestation, and also due to bear-and-tear (Baskin \& Baskin, 2000). Therefore, the use of A. precatorious seeds as a weighing unit especially, where precious metals (gold, silver, platinum), stones and gems have to weigh become dubious and need to be scientifically validated. The later has never been doubted nor scientifically validated ever.

\section{Objective}

The objective of the present study was to find out the rationale behind the use of $A$. precatorious seeds as a weighing unit by Indigenous people and to scientifically validate the indigenous technique.

\footnotetext{
(C) The Author(s), 2021. Published by Cambridge University Press. This is an Open Access article, distributed under the terms of the Creative Commons Attribution licence (http://creativecommons.org/licenses/by/4.0/), which permits unrestricted re-use, distribution, and reproduction in any medium, provided the original work is properly cited.
} 


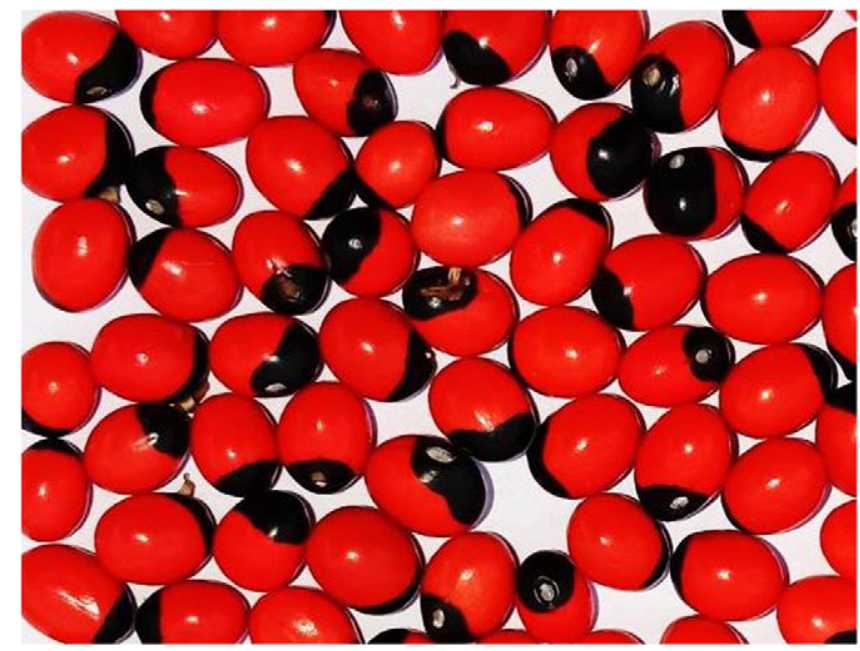

Figure 1. Abrus precatorious (Ratti) seeds.

\section{Methods}

Fully ripened and viable seeds of $A$. precatorious collected from Kangra, Himachal Pradesh, India were used in this experiment. Seed viability was determined through TTC (2,3,5-triphenyl tetrazolium chloride) reduction test. To monitor the change in seed weight, Seeds were subjected to different moisture conditions (soaked in distilled water, placed on moist substratum, kept in a container with high relative humidity, kept in desiccator) and also acid scarified with concentrated $\mathrm{H}_{2} \mathrm{SO}_{4}$ for different durations i.e. $0,30,60,90,120,150 \mathrm{~min}$., washed thoroughly and soaked in distilled water for $24 \mathrm{~h}$ and periodically monitored for any change in weight. In another set of seeds were mechanically scarified at chalazal end with the help of sand paper were also monitored. Further, seeds were transferred to petriplates lined with moist substratum for germination. Data are presented as arithmetic mean of 100 seeds each. The significance of difference was assessed based on the Student's $t$-test.

\section{Results and discussion}

The seeds of $A$. precatorious showed $100 \%$ viability. The later was confirmed by both TTC reduction test and seed germination ( $98 \%$ germination). To evaluate the validity of ITK, seeds were subjected to different moisture conditions. Surprisingly, there was no change in seed weight was observed even after $48 \mathrm{~h}$ of exposure to the above conditions (Tables 1,2). The seed weight remains constant, indicating the complete impermeability of seed coat towards water and air. In contrast, the seed weight of Cicer arietinum L. (used for comparison purpose, procured from IARI, New Delhi, India) increased significantly with increase in relative humidity/moisture (Table 2). The findings strongly supported the use of A. precatorious seeds as a weighing unit. To confirm the impermeability of seed coat toward water the seeds were mechanically (through sand-paper) as well as chemically (conc. $\mathrm{H}_{2} \mathrm{SO}_{4}$ ) scarified. The treatments effectively removed the impermeability of seed coat and resulted in significant increase in seed weight and of course resulted in further germination (Table 1). Seed dormancy in A. precatorious is known (Nautiyal \& Singh, 2015) but, the type of dormancy has never been classified. According to the new seed dormancy classification by Baskin and Baskin (2004), the type of dormancy exhibited by A. precatorious seeds in present study should be classified as physical dormancy (PY). Physical dormancy is caused by water-impermeable seed coat due to the presence of one or more palisade layers of lignified malphigian cells (macrosclereids) tightly packed together and impregnated with water-repellant chemicals and known to occur in some 15 plant families including the Fabaceae (Baskin et al., 2000). In nature, seeds with physical dormancy remain dormant until some factors (high temperature, widely fluctuating 
Table 1. Effect of acid- (concentrated $\mathrm{H}_{2} \mathrm{SO}_{4}$ ) and mechanical-scarification of seeds on seed coat permeability in Abrus precatorious L. Data are average of 100 seeds each, all the differences are significant at $\mathrm{p} \leq 0.01$.

\begin{tabular}{llllllll} 
& \multicolumn{5}{c}{ Acid $\left(\mathrm{H}_{2} \mathrm{SO}_{4}\right)$} & Scarification (Minutes) & \\
\cline { 2 - 7 } Treatments & Control & 30 & 60 & 90 & 120 & 150 & Mechanical Scarification \\
\hline Seed weight (mg) & 116.85 & 134.38 & 158.24 & 171.44 & 178.69 & 186.36 & 172.34 \\
\hline Water uptake (\%) & 0 & 15 & 35.42 & 46.7 & 52.9 & 60.21 & 47.48 \\
\hline Germination (\%) & 0 & $34( \pm 4)$ & $56( \pm 5)$ & $78( \pm 6)$ & $98( \pm 2)$ & $74( \pm 4)$ & $82( \pm 10)$ \\
\hline
\end{tabular}

Table 2. Comparison of change in seed weight of Abrus precatorious $L$ and Cicer arietinum $L$ as affected by different relative humidity. Data are average of 100 seeds each. All the differences are significant at $p \leq 0.01$.

\begin{tabular}{llllll} 
& & \multicolumn{3}{c}{ Relative Humidity (\%) } & \\
\cline { 3 - 5 } & Treatments & 0 & 50 & 100 & Soaked in DW (24 h) \\
\hline \multirow{2}{*}{ A. precatorius } & Seed weight (mg) & 116.98 & 117.04 & 116.96 & 117.04 \\
\cline { 2 - 5 } & Change in seed weight (\%) & 0 & 0 & 0 & 0 \\
\hline \multirow{2}{*}{ C. arietinum } & Seed weight (mg) & 170 & 178 & 183 & 366 \\
\cline { 2 - 5 } & Change in seed weight (\%) & 0 & 4.15 & 7.25 & 114.3 \\
\hline
\end{tabular}

temperature, fire, drying, freezing and passage through the digestive tracts of animals) render the covering layers permeable to water (Baskin, 2003). In the present study, the seeds of A. precatorious required more than 2 hours of acid (conc. $\mathrm{H}_{2} \mathrm{SO}_{4}$ ) scarification to achieve maximum water uptake and seed germination (Table 1). The later indicates the depth of physical dormancy in A. precatorious. Physical seed dormancy can also be affected by microbial action and abrasion by soil particles (Baskin \& Baskin, 2000). However, the presence of abrin, a potent toxin similar to ricin but even more poisonous, in the seed coat of A. precatorious (Dickers et al., 2003; Zhang et al., 2019) protects the seed from pests and microbes, which eventually contribute to the maintenance of impermeability of seed coat/physical dormancy (thereof constant seed weight) for longer period of time. In addition, the smooth, glossy and shiny seed coat significantly reduces the chances of bear and tear/abrasion by soil particles during long run, which further strengthen and validates the ITK. Thus, the present study strongly confirms and validates the use of $A$. precatorious seeds as a weighing unit (ratti) by indigenous people and is reported first time.

Acknowledgements. The financial support by Department of Biotechnology, Government of India under DBT-Star-College scheme is thankfully acknowledged.

Conflicts of interest. None.

Data Availability. Data will be provided whenever requested.

\section{References}

Baskin, C. C. (2003). Breaking physical dormancy in seeds-focusing on the lens. New Phytologist, 158, $229-232$.

Baskin, J. M., \& Baskin, C. C. (2000). Evolutionary considerations of claims for physical dormancy-break by microbial action and abrasion by soil particles. Seed Science Research, 10, 409-413.

Baskin, J. M., \& Baskin, C. C. (2004). A classification system for seed dormancy. Seed Science Research, 14, 1-16.

Baskin, J. M., Baskin, C. C., \& Li, X. (2000). Taxonomy, anatomy and evolution of physical dormancy in seed. Plant Species Biology, 15, 139-152. 
Dickers, K. L., Bradberry, S. M., Rice, P., Griffith, G. D., \& Vale, J. A. (2003). Abrin poisoning. Toxicological Review, 22, 137-142.

McGilp, L., Duquette, J., Braaten, D., Kimball, J., \& Porter, R. (2020). Investigation of variable storage conditions for cultivated northern wild rice and their effects on seed viability and dormancy. Seed Science Research, 30, 21-28.

Mohapatra, L. N. (2018). Field evaluation of ITKs against insect pests of rice. Indian Journal of Traditional Knowledge, 17, 360-364.

Nautiyal, M., \& Singh, B. (2015). Effect of some pre-sowing scarification treatment on water uptake and germination of $A b r u s$ precatorius L. (Ratti). Indian Journal of Drugs, 3, 83-89.

Shrivastava, S. K. (2017). Measurement units of length, mass and time in India through the ages. International Journal of Physical and Social Sciences, 7, 39-48.

Zhang, J., Ma, X., \& Wang, Z. (2019). Real-time and in-situ monitoring of Abrin induced cell apoptosis by using SERS spectroscopy. Talanta, 195, 8-16.

Cite this article: Sharma RK (2021). Physical seed dormancy in Abrus precatorious (Ratti): a scientific validation of indigenous technique Experimental Results, 2, e8, 1-8. https://doi.org/10.1017/exp.2020.64 


\section{Peer Reviews}

\section{Reviewing editor: Dr. Ali Bajwa}

NSW Department of Industry, Wagga Wagga, New South Wales, Australia, 2650

This article has been accepted because it is deemed to be scientifically sound, has the correct controls, has appropriate methodology and is statistically valid, and has been sent for additional statistical evaluation and met required revisions.

doi:10.1017/exp.2020.64.pr1

Review 1: Physical seed dormancy in Abrus precatorious (Ratti): a scientific validation of indigenous technique

Reviewer: Dr. Nadeem Iqbal

Date of review: 05 November 2020

(C) The Author(s), 2021. Published by Cambridge University Press. This is an Open Access article, distributed under the terms of the Creative Commons Attribution licence (http://creativecommons.org/licenses/by/4.0/), which permits unrestricted re-use, distribution, and reproduction in any medium, provided the original work is properly cited.

Conflict of interest statement. I declared that I have no conflict of interest with this paper

Comments to the Author: Overall, a very well written paper on an important subject. The study was well designed and executed taken into account all important parameters. Results were appropriately described and discussion was up to the mark. However, it needs some improvement in introduction section. Goals/ objectives are not clearly defined and followed throughout the manuscript. Also, abstract should indicate data from results and discussion section.

\section{Score Card}

Presentation

Is the data presented in the most useful manner? (40\%)

Does the paper cite relevant and related articles appropriately? (30\%)

Context

Does the title suitably represent the article? (25\%)

Does the abstract correctly embody the content of the article? (25\%)

Does the introduction give appropriate context? (25\%)

Is the objective of the experiment clearly defined? (25\%) 
Are the limitations of the experiment as well as the contributions of the experiment clearly outlined? (20\%) 


\section{Review 2: Physical seed dormancy in Abrus precatorious (Ratti): a scientific validation of indigenous technique}

Reviewer: Dr. Shah Fahad

Date of review: 15 November 2020

(c) The Author(s), 2021. Published by Cambridge University Press. This is an Open Access article, distributed under the terms of the Creative Commons Attribution licence (http://creativecommons.org/licenses/by/4.0/), which permits unrestricted re-use, distribution, and reproduction in any medium, provided the original work is properly cited.

Conflict of interest statement. Reviewer declares none

Comments to the Author: This is a paper which reviews the role of seed dormancy in Abrus precatorious. The author has done good work. However, the actual text needs a lot of work I feel. I have the following comments, but they are not exhaustive, I could have pointed out more. However, I hope my comments will help the overall feel of the paper.

1. Title should be modified.

2. English should improve by a native person. The paper suffers from a poor English structure throughout and cannot be published or reviewed properly in the current format. The manuscript requires a thorough proofread by a native person whose first language is English. The instances of the problem are numerous and this reviewer cannot individually mention them. It is the responsibility of the author(s) to present their work in an acceptable format. Unless the paper is in a reasonable format, it should not have been submitted.

3. The novelty of the study needs to be highlighted compare to other similar studies.

4. Discussion is weak. The discussion needs enhancement with real explanations not only agreements and disagreements. Authors should improve it by the demonstration of biochemical/physiological causes of obtained results. Instead of just justifying results, results should be interpreted, explained to appropriately elaborate inferences. Discussion seems to be poor, didn't give good explanations of the results obtained. I think that it must be really improved. Where possible please discuss potential mechanisms behind your observations. You should also expand the links with prior publications in the area, but try to be careful to not over-reach. For the latter, you should highlight potential areas of future study.

5. The scientific background of the topic is poor. In "Introduction" and "Discussion", the authors should cite recent references between 2016-2020 from JCR journals (with impact factor) about recent achievements on the other factors affects on Physical seed dormancy in Abrus precatorious (Ratti): a scientific validation of indigenous technique.

6. A detailed "Conclusion" should be provided to state the final result that the authors have reached. Please note you only need to place your conclusion and not keep putting results, because these have already been presented in the manuscript.

\section{Score Card}

Presentation

Is the article written in clear and proper English? (30\%)

Does the paper cite relevant and related articles appropriately? (30\%) 


\section{Context}

Does the abstract correctly embody the content of the article? $(25 \%)$

Does the introduction give appropriate context? (25\%)

Is the objective of the experiment clearly defined? $(25 \%)$

Analysis

Does the discussion adequately interpret the results presented? (40\%)

Is the conclusion consistent with the results and discussion? (40\%)

Are the limitations of the experiment as well as the contributions of the experiment clearly outlined? $(20 \%)$ 